УДК 378.4:61(410)

Камілла Магрламова, кандидат педагогічних наук, викладач кафедри мовної підготовки ДЗ “Дніпропетровська медична академія МОЗ України”

\title{
РЕТРОСПЕКТИВНИЙ АНАЛІЗ ВИЩОЇ МЕДИЧНОЇ ОСВІТИ У ВЕЛИКІЙ БРИТАНІЇ
}

У статті викладено результати ретроспективного аналізу вищої медичної освіти у Великій Британії; виокремлено та обтрунтовано критерії, що дозволили класифікувати досліджуване явище в його еволюиійному поступі. Стаття містить результати аналізу взаємозв'язків ринку праиі та вищоі професійної підготовки майбутніх лікарів у Великій Британії та їх особливостей, щзо вирізняють їх від інших краӥн. Простежено динаміку змін чисельності студентів-медиків у XXI cm. та проаналізовано чинники, щзо ї̈ обумовлюють. Описано структуру медичної освіти у Великій Британії на сучасному етапі та розкрито теоретико-методологічні підходи до неї.

Ключові слова: система охорони здоров'я, вища медична освіта, професійна підготовка, історикопедагогічний аналіз, сімейна медицина, Велика Британія.

Puc. 2. Лim. 13.

Kamilla Mahrlamova, Ph.D. (Pedagogy), Lecturer of the Language Training Department, State Establishment "Dnipropetrovsk Medical Academy of the Ministry of Health of Ukraine"

\section{THE RETROSPECTIVEANALYSIS OFHIGHER MEDICALEDUCATION IN GREAT BRITAIN}

The article presents the results of the retrospective analysis of higher medical education in Great Britain. The criteria which allowed to classify the investigated phenomenon in its evolutionary progress are isolated and substantiated. The article contains the results of an analysis of the relationship between the labor market and the higher professional training of future doctors in the UK and their peculiarities that distinguish them from other countries. The dynamics of changes in the number of medical students in the XXI century is examined and the factors that determine it are analyzed. The structure of medical education in Great Britain at the present stage is described and the theoretical and methodological approaches to it are revealed.

Keywords: health system, higher medical education, vocational training, the historical and pedagogical analysis, Great Britain.

П остановка проблеми. Досліджуючи будь-яке явище чи процес не можна обійтися без екскурсу до їх першоджерел, адже саме вивчення передумов їх виникнення сприяє глибшому і всебічному аналізу їх сугності. Тому перш ніж, аналізувати сучасний стан професійної медичної освіти у Великій Британії, простежимо ії витоки.

Одним із напрямів модернізації вищої медичної освіти в Україні $\epsilon$ врахування прогресивних ідей та практичних здобутків провідних країн, які за останні роки досягли значних успіхів у реформуванні своїх освітніх систем, зокрема в галузі медицини. У цьому аспекті значний науковий та практичний інтерес становить досвід Великої Британії, дослідження медичної освіти якої може принести користь нашій країні як у теоретичному, так і в практичному аспекті.

Огляд науково-педагогічної та науковометодичної літератури свідчить, що історію професійної медичної освіти у Сполученому Королівстві досліджувало чимало українських, російських та зарубіжних науковців [Арапов М.В.; Верхратський С.А; Паламаренко, дисер, С. 34 40; Allen,; Rivlin; 150 years]. Проте у кожній науковій розвідці увагу дослідника сфокусовано на різних аспектах розвиткупрофесійної медичної освіти: сімейних лікарів [Паламаренко, дисер, C. 34-40]; фахівців із фізичної реабілітації [Гук 2015], ветеринарів [Канівець 2015 ], окремих періодів розвитку - Середньовіччя [Allen; Health and Medicine in Mediaval England]; XIX ст. [Medical Education in 1858; Rivlin]; проміжок часу у 150 років [150 years]; інших країн - Свропи [Логуш 2016], Канади [Лавриш 2009], Австрії [Кліщ 2013], Польщі [Хоменко 2017] [12].

Мета статті дослідити та проаналізувати становленя та розвиток медичної освіти в університетах Великої Британії.

Виклад основного матеріалу. Варто зазначити, що саме становлення і розвиток медичної освіти в університетах Великої Британії ще не були предметом дослідження. Відтак, проаналізуємо i систематизуємо наявну інформацію, акцентуючи увагу на підготовку майбутніх лікарів у системі вищої школи досліджуваної країни.

Привертає увагуградація етапів університетської освіти уВеликій Британіï, розробленій Dornan T.O. Дослідник систематизує процес формування системи вищої освіти наступними чином:

Периий етап (XII - XIII ст.) - розвиток 


\section{РЕТРОСПЕКТИВНИЙ АНАЛІЗ ВИЩОЇ МЕДИЧНОЇ ОСВІТИ У ВЕЛИКІЙ БРИТАНІЇ}

первісних училищ, утворення Оксфордського i Кембриджського університетів. Другий етап (XIV - XV ст.) - формування головних корпоративних елементів англійських університетів, заснування шотландських університетів, проведення першої реформи вищої освіти. Третій етап (XVI-XVII ст.) - прийняття перших статутів, звільнення університетів від церкви, запровадження кандидатських іспитів для одержання вченого ступеня. Четвертий етап (XVIII - XIX ст.) запровадження радикальної реформи освітньої системи, започаткування вступних та державних іспитів, розширення змісту професійної підготовки тощо. П'ятий етап (кінець ХІХ ст. теперішній час) - утворення бінарної системи вищої освіти, модернізація структури вищих навчальних закладів, змісту та методів навчання, реформування вищої школи [5].

Беззаперечно погоджуємося із запропонованою класифікацією. Загалом університетська медична освіта пройшла той самий шлях розвитку. Однак медична освіта у Великій Британії у своїй генезі мала неповторну специфіку, яка не могла бути відображеною у класифікації, але яку доцільно висвітлити.

Найбільш повною і наближеною до нашого дослідження $є$ класифікація етапів становлення і розвитку професійної медичної освіти у Великій Британії, запропонована I. Паламаренко. Дослідниця виокремлює 5 етапів становлення й розвитку медичної професійної освіти у Великій Британії, починаючи зі стародавніх часів і дотепер:

Перший eman - це стародавній, античний дохристиянський період.

Другий етап - розвиток ідеології медичної освіти, який настав із поширенням християнства у Британії наприкінці VI ст.

Tретій етап - медицина Середньовіччя.

Четвертий етаn - розквіт медицини як науки 3 пізнього Середньовіччя (епоха Відродження та Реформацій - кінець XV - початок XVI ст.) і до середини XX ст.

П'ятий етап - зародження і розвиток загальної практики - сімейної медицини від середини XX ст. дотепер [1], [3].

Цілком погоджуємось із класифікацією етапів становлення і розвитку професійної медичної освіти. Однак, зауважимо, що у запропонованій класифікації при детально описаних етапах розвитку не зовсім чітко простежуються критерії ïх виокремлення. Крім того, історія становлення професійної підготовки сімейних лікарів, що до певної міри звужує класифікацію, зокрема п'ятий етап. Саме він викликає найбільший інтерес у контексті завдань нашого дослідження. Крім того увагу необхідно сконцентрувати саме на аналіз університетської медичної освіти, яка стала прообразом медичної освіти у іï сучасній формі.

Критеріями виокремлення етапів розвитку університетської освіти майбутніх медиків у Великій Британії для нас слугуватиме наступне:

- виникнення нових медичних шкіл;

- поява нового законодавчого забезпечення щодо медичної освіти та органів, що сприяють його реалізації; - інновації в навчальному процесі підготовки майбутніх лікарів [6].

Аналізуючи кількість наявних медичних шкіл у Великій Британії та історію їх створення, спостерігаємо таку картину: 5 відрізків часу, коли масово почали відкриватися медичні освітні заклади (див. рис. 1). Вони стануть первинним орієнтиром для побудови власної класифікації етапів становлення і розвитку медичної освіти в університетах Великої Британії.

3 огляду на зазначені критерії, відправним пунктом нашого аналізу стає XIII ст., коли медицину почали вивчати як самостійну навчальну дисципліну в Оксфордському університеті. Причому, як відмічає англійський дослідник Філіс Аллен (Phyllis Allen), тодішнє вивчення медицини було чисто теоретичним без практичної підготовки майбутніх фахівців, як і в інших континентальних університетах Свропи [2].

Пройшло не менше 2 століть, перш ніж у Великій Британії з'явилася перша медична школа - у шотландському містечку Абердин у 1497 р. [7;9].

Вже незабаром у 1518 р. найкращі лікарі країни об'єдналися, створивши Лондонську королівську медичну колегію. Її завданням стала розробка іспиту з медицини, його прийом та видача дозволу на ведення медичної практики [1;3]. Отже, 3'явилися певні правила, що узаконювали i регулювали видачу дипломів лікаря

Упродовж тривалого часу (з XIII по XVII ст.) здобути ступінь $з$ медичної освіти можна було кількома шляхами:

- в університеті (на той час існували Оксфордський, Кембриджський, Абердинський);

- через королівський патронат;

- через церковний патронат.

Іншими словами, останні два способи - це набуття певних медичних навичок і перейняття досвіду у практикуючого лікаря або королівського або монастирського, тобто без теоретичної підготовки [7]. Однак, на думку Філіса Аллена (Phyllis Allen), будь який практикуючий терапевт XVII ст. вже мав університетський диплом [Allen], тобто мав теоретичні знання. Таким чином, відмітною рисою тогочасної класичної 


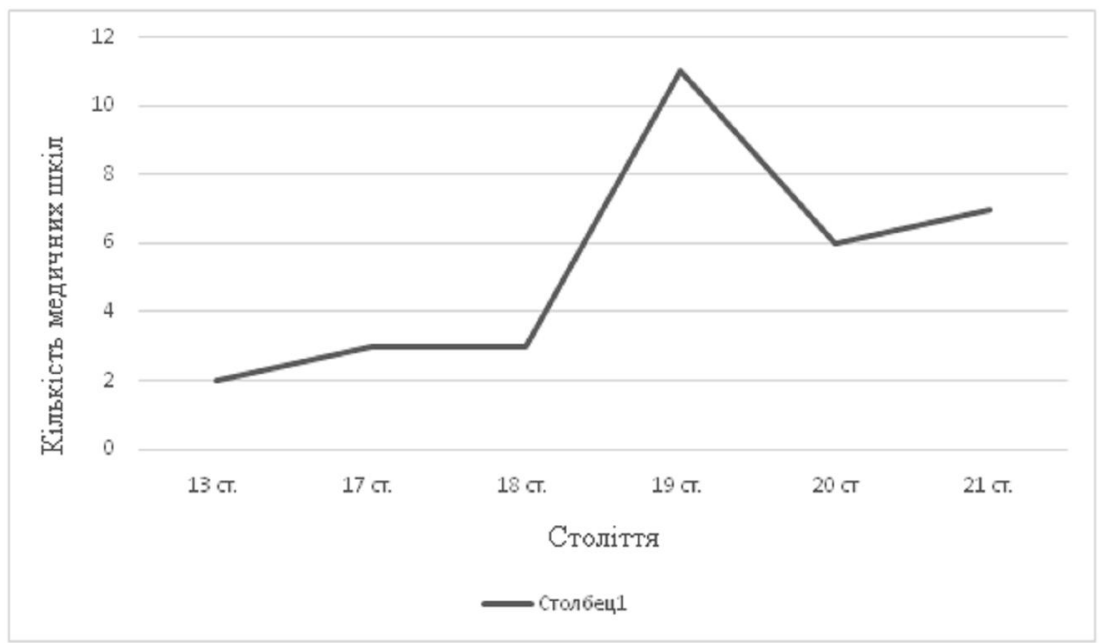

Рис. 1. Динаміка росту медичних шкіл у Великій Британії

Джерело: розроблено автором на основі опрачювання [150 Years of Medical School Achievements, Allen Ph.; Bates V; Bonner T.N.; Dornan T.; Health and Medicine in Medieval England; Medical Education in 1858; Reinarz J.; Report of the Royal Commission; Rivlin J.J.; The State of Basic Medical Education; Waddington I.]

університетської медичної освіти залишалася теоретична підготовка. Так, випускники університетів Оксфорда і Кембриджа (Оксбриджа) вивчали твори Гіппократа, Галлена, а на випускному екзамені мали захистити латинською мовою 2 роботи. Одну роботу захищали перед професором медицини, іншу - перед своїм колегою. Причому теми обирали самі. Прийнятно було і те, що випускник міг заплатити, щоб хтось інший захистився за нього [3]. Доцільно згадати також, що шотландський університет, на відміну від англійських, приймав на навчання студентів усіх релігій. Університети ж Оксфорда i Кембриджа (Оксбриджа) обмежували доступ до освіти англіканцям-нон-комформістам [11].

Отже, враховуючи виокремлені критерії, період 3 XIII ст. по XVII ст. можна назвати етапом зародження $i$ становлення системи університетської професійної медичної освіти.

У XVII ст. всі галузі наук, зокрема і медицина, починають широко використовувати наукові методи пізнання. Цей новий підхід має великий вплив на медицину, яка набуває рис науковості і точності, пізнати яку без належної теоретичної підготовки вже неможливо [5]. Університети включають у свої навчальні плани практичну підготовку майбутніх лікарів. Однак, такі зміни завоювали собі місце дуже повільно [12].

Таким чином, XVII ст. стає переломним у становленні вищої професійної медичної освіти у Великій Британії: лікування хворих поступово почало переходити на інший рівень - знання теорії медицини та практична підготовка.

Разом 3 тим, англійський науковець Джонатан
Рейнарц (J. Reinarz) наголошує, що історію сучасної медичної освіти варто простежувати із вчення Германна Боерхааве (Hermann Boerhaave, 1668 - 1738) та відкриття медичної школи в Лайдені на початку XVIII ст. Клінічні методи навчання лікарів, що використовував Г.Боерхааве, були відомі по всій Європі. Лікар-педагог поєднував лекції з регулярним відвідуванням лікарні і лікуванням пацієнтів. Студенти, майбутні лікарі, звідусіль приїздили до медичної школи Лайдена, щоб “відвідати заняття з “приліжкової педагогіки” [10].

На початку XVIII ст. регулярна медична практика улікарнях стала обов'язковою частиною підготовки майбутніх лікарів у 8 університетах, зокрема 2 в Англії, 1 в Ірландії, 5 в Шотландії (причому 2 з них в Абердині), 7 коледжах терапевтів і хірургів (2 в Англії, 3 в Шотландії та 2 в Ірландії) [14]. Якщо у попередньому столітті тих, хто займався лікуванням хворих, умовно поділяли на три групи: лікарі загального профілю, хірурги та аптекарі, то прийдешнє століття почало висувати нові вимоги до майбутнього лікаря. Фахівець лікарської справи мав володіти знаннями і навичками не лише у своїй спеціальності, але й у споріднених. Так, у Вимогах до випускника медичної школи йдеться про те, що терапевт повинен прослухати теоретичний курс лекцій i пройти практику із хірургії та фармакології. А хірург відповідно - лекції із загальної медицини і фармакології [9].

Загалом, XVIII ст. можна схарактеризувати як століття кардинальних змін у професійній підготовці майбутніх лікарів: розширення переліку 


\section{РЕТРОСПЕКТИВНИЙ АНАЛІЗ ВИЩОЇ МЕДИЧНОЇ ОСВІТИ У ВЕЛИКІЙ БРИТАНІЇ}

медичних дисциплін; введення практичної складової у підготовку, здача кваліфікаційних екзаменів, впровадження ліцензій на лікарську практику. Екзамени приймали уповноважені органи в Англії, Шотландії та Ірландії. В Англії таке право мали Королівський коледж терапевтів (створений 1518 р.) Королівський коледж хірургів (1745 р.) та Товариство аптекарів (1617 р.).

3 урахуванням вище викладеного, цей проміжок часу в історії професійної університетської медичної підготовки у Великій Британії можна вважати таким, що дозволив сформувати систему професійної підготовки майбутніх лікарів, тобто системо-формувальним.

XIX ст. стало “золотою ерою” для медичних шкіл Сполученого королівства. “Лондонська модель” вищої медичної освіти, яка домінувала довгий час в історії медичної освіти, поступово давала шлях провінційним школам 3 їх “свіжими перспективами" на медичну освіту” [8]. Імпульсом для появи таких шкіл стали різноманітні відкриття в різних галузях науки: хімії, фізики, біології, техніці тощо. В медицині почали широко використовувати їх здобутки, що вимагало нових підходів у підготовці майбутніх лікарів. Медична освіта стає “науковою освітою, що базується на фактах" [13].

Почали з'являтися нові окремі медичні школи та школи в рамках університетів. Їх навчальні плани були дуже різними, однак спільним було те, що медичний навчальний рік було поділено на 2 семестри: зимовий тривалістю 6 місяців, який розпочинався у жовтні, та 3 -х місячний літній семестр, який розпочинався у травні [12].

Спостерігається схожа тенденція у підготовці аптекарів, загальних лікарів і хірургів - вивчення теорії та обов'язкова практична підготовка зі своєї спеціальності та споріднених. Майбутні лікарі вивчали загальну медицину, фармакологію, анатомію, лікування дітей, і навіть акушерство.

У цей період було введено ще 3 інновації. Всі вони з ініціативи медичної школи Кембриджського університету

- у 1829 р. відвідування лекцій стало обов'язковим для студентів-медиків;

- складовою випускного екзамену стало написання дослідницької роботи;

- у 1842 р. було введено здачу клінічного екзамену [12].

Підсумовуючи всі нововведення в професійній медичній підготовці в університетах того часу, зазначимо такі спільні вимоги:

- тривалість загального медичного курсу в університеті становить не менше, як 4 роки;

- для отримання диплому необхідний досвід у веденні вагітності та прийомі пологів, тобто новій дисципліні - акушерстві;

- обов'язковий курс лекцій із загальної медицини;

- практична підготовка у лікарнях.

Заслуговує на увагу і той факт, що у 1863 р. саме Рада із загальної медицини підняла питання про перевантаженість навчальних планів підготовки лікарів. Рада підтримала бажання майбутніх лікарів “дати студенту більше часу для самоосвіти" [1].

Отже, відповідно до наших критеріїв, наступним етапом розвитку медичної освіти в університетах Великої Британії є XVIII - XIX ст. Ураховуючи всі описані зміни та інновації, назвемо цей проміжок часу - етапом професіоналізації.

Наступним піком у розвитку університетської медичної підготовки, як видно із рис. 2, стало XX ст. 3'являються 6 нових медичних шкіл, зокрема Ноттінгем (1966 р.), Данді (1967 р.), Сайтгемптон (1969 р.), Кембридж, Лайсестер (1975 р.), Імперіал (1997 р.).

За влучним висловом британського науковця Тіма Дорнана (T. Dornan), який займався питаннями становлення медичної освіти в Об'єднаному Королівстві, “настали дивовижні часи для лікарів, які навчають студентів-медиків”, результатом яких стало те, що “обличчя медичної освіти у XX столітті змінилося до невпізнання” [6].

На початку нового століття основою медичної освіти у Великій Британії залишалася практика і “навчання біля ліжка пацієнта" [10]. Однак потреба у грунтовних теоретичних знаннях з медицини зумовила введення до навчальних планів підготовки лікарів таких курсів, як анатомія, фізіологія, біохімія і фармакологія в якості обов'язкових, які передують клінічним дисциплінам і клінічній практиці. Таким чином, до-клінічна підготовка майбутніх лікарів і клінічна практика складали усю підготовку майбутніх лікарів. Зауважимо, що до введення реєстрації лікарів у 1953 р. лікар-випускник міг практикувати без жодних інших форм стажування i без жодних вимог щодо його подальшого навчання і підвищення кваліфікації [10].

Радикальні зміни у світовій медичній освіті, в тому числі і британській, пов'язують із іменами Уільяма Ослера (William Osler) та Абрагама Флекснера (Abraham Flexner). Незважаючи на те, що обидва були американцями, відіграли значну роль у змінах, що відбулися у медичній освіті Великої Британії.

У. Ослер (W. Osler), який займався патологією, притримувався думки, що лікар має більше 


\section{РЕТРОСПЕКТИВНИЙ АНАЛІЗ ВИЩОЇ МЕДИЧНОЇ ОСВІТИ У ВЕЛИКІЙ БРИТАНІЇ}

цікавитися і дбати про пацієнта, ніж про його захворювання. Водночас, як педагог, котрий навчав майбутніх лікарів, він був переконаний, що найкращий учитель для студентів-медиків це захворювання, а навчальний процес повинен здійснюватися, насамперед, біля ліжка пацієнта, а не в лекційному залі. Свої погляди У. Ослер (W. Osler) виклав у посібнику “The Principles and Practice of Medicine", ставши відомим у всьому світі. Його було запрошено очолити медичну кафедру Оксфордського університету у 1905 році, де він продовжував втілювати у життя своє бачення професійної підготовки майбугніх лікарів [6].

Стосовно А. Флекснера (А. Flexner), необхідно зазначити, що не будучи навіть лікарем, його вважають “далекоглядним педагогом, який підняв стандарти медицини у всьому світі, зробивши біомедицину основою лікування пацієнтів" [6]. До його заслуг у галузі медичної освіти належать також зміни у характері медичної освіти. Він був першим, хто запровадив активне навчання, орієнтоване на учня, наголошував на тому, що освіта має бути соціально відповідальною, а учні повинні брати активну участь у житті суспільства.

Рекомендації А. Флекснера (A. Flexner) були взяті до розробки Американською медичною асоціацією, а в 1910 р. його було запрошено до Галдейнської комісії (Haldane Commission) в Лондоні, яка займалася вивченням стану медичної освіти у Великій Британії. За результатами роботи вищеозначеної комісії, А. Флекснер (А. Flexner) відзначав, що сильною стороною британської системи підготовки лікарів є її орієнтація на практику, стажування. Разом з тим, вона $\epsilon$ набагато слабшою за німецьку систему підготовки лікарів у біомедичних науках [6].

Отже, внесок обох педагогів, що займалися підготовкою майбутніх лікарів, у розвиток медичної освіти $є$ неоціненним. У. Ослер (W. Osler) та А. Флекснер (A. Flexner) окреслили напрями, за якими продовжила розвиватися медична освіта у Великій Британії у ХX ст.

Повсюди у британських медичних школах почали створювати медичні групи чи комітети 3 етики для вирішення назрілих питань. Цікаво, що до таких груп включали не лише викладачів університету та практикуючих лікарів, але й студентів. Останні вносили пропозиції щодо формування навчальних планів і внесення до них курсів та дисциплін гуманістичного спрямування. Так, у 1982 р. до Комітету 3 етики Манчестерського університету входило 4 студенти, які від імені усього студентства висловили бажання прослухати лекції та семінари 3 лікарської етики [5].

Інша англійська організація - Асоціація 3 отримання медичної освіти (ASME - Association for the Study of Medical Education) відіграла ключову роль у вивченні та поширенні зусиль в міжнародному масштабі “гуманізувати медичну освіту" [6].

Аналіз діяльності тогочасних медичних шкіл свідчить, що окрім впровадження окремих нових гуманітарних дисциплін, гуманістичний підхід медичної освіти в університетах Великої Британії також охоплював:

- націленість усієї професійної підготовки лікаря на підвищення турботи про пацієнта, тобто на те, що лікування має стати пацієнтоорієнтованим;

- розвиток вмінь і навичок майбутніх лікарів брати на себе відповідальність за медичну професію з питань моральності, наукової та медичної етики;

- формування у майбутніх лікарів розуміння їх взаємозв'язків із соціумом, та турботою про здоров'я його членів.

Так, у доповіді Королівської комісії з медичної освіти (Royal Commission on Medical Education ) у 1968 р. йдеться про те, що студент медичної школи "повинен вивчати про людину все, не тільки як про пацієнта, а передусім, як про соціальну істоту" [1].

Відтак, гуманістичність професійної медичної освіти набувала нової риси - соціальної спрямованості. В університетах почали навчати майбутніх лікарів умінню спілкуватися, зокрема спілкування почали розглядати не лише як діагностичний засіб, а й як гуманістичну складову [3]. Навчальні плани медичних шкіл включали дисципліни зі спілкування, медичної етики, відповідних законів та інших фундаментальних дисциплін, що були націлені на ознайомлення студентів із постійно мінливими системами охорони здоров' я і догляду, мульти-професіоналізм та на турботу про здоров'я членів суспільства [2]. Медична ж практика студентів у клініці дозволяла їм набути інших необхідних навичок через індивідуальне лікування і догляд за пацієнтом.

Виходячи із наших класифікуючих критеріїв, зазначимо, що у XXI ст. було відкрито 7 нових медичних шкіл, 4 з них в Англії: Медична школа Брайтона і Сасекса в університетах Брайтона і Сасекса, Медична школа Галл Йорка в університетах Галла і Йорка, Медична школа Пенінсьюла в університетах Ексетера і Плімута, університет Медичної школи Іст Англії [10].

Найбільшою інновацією унавчальному процесі 


\section{РЕТРОСПЕКТИВНИЙ АНАЛІЗ ВИЩОЇ МЕДИЧНОЇ ОСВІТИ У ВЕЛИКІЙ БРИТАНІЇ}

підготовки майбутніх лікарів можна вважати впровадження програми із забезпечення якості медичної освіти (QABME - Quality Assurance of Basic Medical Education). Зупинимося на $\dddot{1}$ особливостях детальніше. Ця програма охоплює 2 вагомих аспекти. Перший - усі медичні школи Великої Британії повинні щорічно подавати до Ради із загальної медицини (GMC) всі зміни у своїх навчальних планах, з поясненням можливих ризиків і впровадженням інновацій. Другий - усі медичні школи мають пройти через цикл інспекцій 3 якості. Учасниками таких інспекційних комісій стають члени GMC, які відомі як “відвідувачі" (visitors). Це - запрошені викладачі, представники клінічної практики, студенти та інші особи з різноманітним досвідом у сфері охорони здоров'я (адміністратори, законодавці, реабілітологи тощо) [10].

На основі їх відгуків Рада із загальної медицини (GMC) вирішує, чи відповідають університети установленим стандартам якості і має право включати і виключати університети із спискутих медичних освітніх закладів, які видають первинну медичну кваліфікацію - дипломи бакалавра медицини (Bachelor of Medicine) i бакалавра хірургї (Bachelor of Surgery).

Викладене вище дає підстави узагальнити історію розвитку університетської медичної освіти наступним чином (Рис. 2.): освіти. Однак, з урахуванням еволюційного характеру її поступу, варто розглядати цей етап розвитку системи вищої професійної медичної освіти як етап модернізації.

Висновки. У XX ст. гуманність майбутнього лікаря, індивідуальний догляд за пацієнтом, уміння спілкуватися з пацієнтом, його/їі родичами, зі своїми колегами - все, чому навчали у медичній школі, зумовили і назву наступного етапу розвитку професійної медичної освіти гуманізація та соиіалізація.

Таким чином, виокремлені критерії (поява нових медичних шкіл, нововведення в законодавчому забезпеченні, інновації в навчальному процесі в університетах Великої Британії) дозволили систематизувати історію професійної медичної освіти в університетах Великої Британії та умовно поділити ії на 5 етапів.

\section{ЛIТЕРАТУРА}

1. 150 Years of Medical School Achievements: Improving Lives - London: Medical School Council, 2008. $-32 p$.

2. Allen Ph. Medical Education in the 17th Century England / Ph. Allen [Електронний ресурс]. - Режим docmyny: https://www.jstor.org/stable/24619539?seq =1\#page_scan_tab_contents. - Назва з екрану.

3. Bates V. Yesterday's Doctors: The Human Aspects of Medical Education in Britain, 1957-93 / V. Bates // Medical History. - 2017. - Vol. 61 (1). - pp.48-65

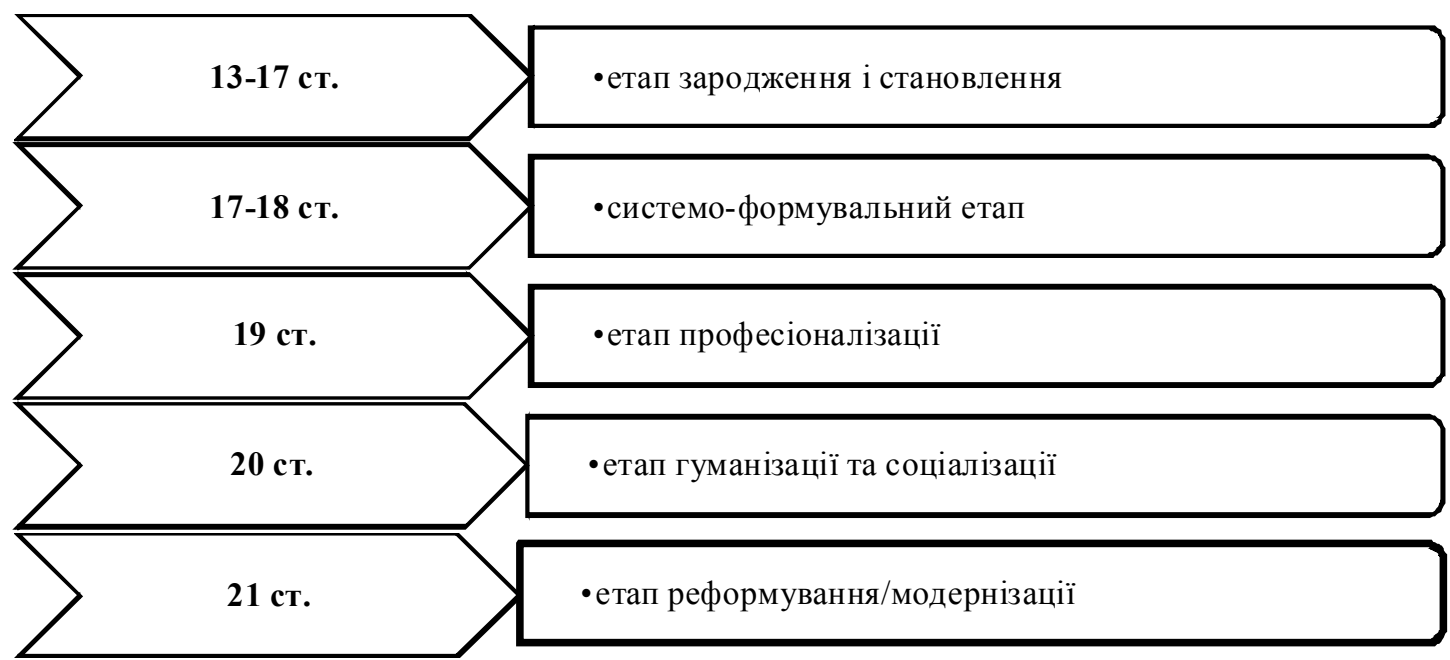

Рис. 2. Етапи становлення і розвитку медичної освіти в університетах Великої Британії Джерело: самостійно розроблено автором

За словами професора Джона Коена (Jon Cohen), декана Медичної школи Брайтона i Сасекса, медична освіта у Великій Британії у своєму розвитку ніколи не йшла революційним шляхом, а радше еволюційни [13]. Іншими словами, розвиток медичної освіти ніколи не припинявся. Триває він і нині. XXI ст. ми назвали етапом реформування університетської медичної
[Електронний ресурс]. - Режим доступу: https:// www.cambridge.org/core/services/aop-cambridgecore/content /view/ B85B53EBCDB75F715319 746C32DDFB36/S0025727316001009a.pdf/divclass-title-yesterday-s-doctors-the-human-aspects-ofmedical-education-in-britain-1957-93-div.pdf. Назва з екрану.

4. Brown J. How Clinical Communication has become a Core Part of Medical Education in the UK / 

ЗБЕРЕЖЕННЯ ТРАДИЦІЙ УКРАЇНСБКОГО ХОРОВОГО МИСТЕЦТВА

J. Brown // Medical Education. - 2007. - Vol. 42 (3). pp. 271-278.

5. Dornan T. O. Apprenticeship and the "New Medical Education" / T. Dornan // Journal of the Royal Society of Medicine. - 2005. - Vol. 9(3). - pp.91-95 [Електронний ресурс]. - Режим доступу: https:// www.ncbi.nlm.nih.gov/pmc/articles/PMC1079407/ . Назва з екрану.

6. General Medical Council. Tomorrow's Doctors Recommendations on

7. Health and Medicine in Medieval England / Learning History Site. [Електронний ресурс]. Режим достуny: http://www. historylearningsite. co.uk/health_and medicine in medieval .htm .-Назва з екрану.

8. Kopelman P. The Future of UK Medical Education Curriculum - What Type of Medical Graduates Do We Need? / Peter Kopelman // Future Hospital Journal. 2014. - Vol. 1. - No 1. - pp.41-46.
9. Medical Education in 1858 [Електронний pecypc]. - Режим достуnу: http://www.thornber.net/ medicine/html/scimedph.html. - Назва з екрану.

10. Reinarz J. Towards a History of Medical Education in Provincial England / J. Reinarz [Електронний ресурс]. - Режим доступу: http:// www.evolve 360. co.uk/data/10/docs/17/17reinarz.pdf. - Назва з екрану.

11. Report of the Royal Commission on Medical Education 1965-1968. - London: HMSO, 1968. $302 \mathrm{p}$.

12. Rivlin J. J. Getting a Medical Qualification in England in the Nineteenth Century / J. J. Rivlin [Електронний ресурс]. - Режим доступу: http:// www.evolve360.co.uk/data/10/docs/09/09rivlin.pdf. Назва з екрану.

13. Smith R. Medical Discipline: the Professional Conduct of the GMC 1858 - 1990 / Russell G. Smith. Oxford: Oxford University Press, 1994. - 117 p.

Стаття надійшла до редакції 28.12.2017

УДК 7.071.2

Світлана Теодорович, викладач кафедри музикознавства та хорового мистецтвва Михайло Ковбасюк, доцент кафедри музикознавства та хорового мистецтва факультету культури і мистеитв Львівського національного університету імені Івана Франка

\section{ПСИХОЛОГІЧНА ЗРІЛІСТЬ ДИРИГЕНТА-ХОРМЕЙСТЕРА ЯК ВАЖЛИВА ЗАПОРУКА ЗБЕРЕЖЕННЯ ТРАДИЦЙ УКРАЇНСЬКОГО ХОРОВОГО МИСТЕЦТВА}

У статті відслідковано традииї розвитку украӥнського хорового мистецтва від давніх часів до наших днів. Акиентовано увагу на психологічному розвитку диригента-хормейстера як очільника та наставника хорового колективу. Звернено увагу на причини непорозумінь $і$ конфліктів в хоровому колективі $i$ методи їх усунення, наголотено на важливій ролі вміння зберігати рівновагу $і$ душевний спокій в непростій, емоиійно насиченій роботі диригента-хормейстера, досліджено позитивний вплив мови-прім на покращення психологічного клімату в мистечькому колективі.

Ключові слова: хоровий колектив, свідомість, мова-прім, психологічна зрілість.

Лim. 7.

Svitlana Teodorovych, Lecturer of the Musicology and Choral Art Department Mykhaylo Kovbasyuk, Associate Professor of the Musicology and Choral Art Department Culture and Arts Faculty Lviv Ivan Franko National University

\section{PSYCHOLOGICAL MATURITY OF A CONDUCTORAND CHOIRMASTER AS AN IMPORTANT CONDITION OF PRESERVING UKRAINIAN CHOIR ART TRADITIONS}

The article studies the traditions of development of Ukrainian choral art from ancient times to present days. The article focuses on psychological development of a conductor and choirmaster as the supervisor and head of a choir. The special attention is paid to singing education which started in the period of ruling of Volodymyr and Yaroslav, spread in the middle Ages and led to the foundation of a court choir formed of the best singers in Ukraine in the 15th century. Then the origination and development of polyphonic singing is studied, and also partsong, cantus and psalms. The article emphasizes the role of Mykola Diletskiy who initiated the first theoretical works on development of singing voice and whose traditions were followed by well-known composers such as M. Berezovskiy, A. Vedel, D. Bortnyanskiy in their choral concertos. The transition from classicism to romanticism in Ukraine is also studied in the article, which was reflected in the works of famous composers M. Verbytskiy, I. Lavrivskiy, N. Nishchynskiy and others, and in the works of the founder of Ukrainian classical music M. Lysenko in particular. Further development of Ukrainian choral art is studied, which leading Ukrainian musicians L. Dychko, V. Zubytskiy, V. Kaminskiy and others pay attention to.

The article studies the psychological aspect of the work of a choral conductor, who directly realizes the 